\title{
Exchange rate determination and the flaws of mainstream monetary theory ${ }^{1}$
}

\author{
Determinação da taxa de câmbio e as falhas \\ da teoria monetária convencional
}

HEINER FLASSBECK ${ }^{2}$

RESUMO: Os países em desenvolvimento geralmente precisam de flexibilidade e um número suficiente de instrumentos para prevenir a volatilidade excessiva. A evidência não apoia a crença ortodoxa de que o desempenho dos mercados financeiros internacionais flutuantes ajustará as taxas de câmbio ao seu "equilíbrio". Na realidade, as taxas de câmbio sob um regime flutuante provaram ser altamente instáveis, levando a longos períodos de desalinhamento. A experiência com indexação também não foi satisfatória: a taxa de câmbio não pôde ser corrigida em casos de choque externo ou desalinhamento. Dada essa experiência, os regimes “intermediários” são preferíveis quando há instabilidade nos mercados financeiros internacionais.

PALAVRAS-CHAVE: regime de taxa de cambio; choques externos; taxas de cambio flexíveis; mercados financeiros; formas de indexação.

ABSTRACT: Developing countries in general need flexibility and a sufficient number of instruments to prevent excessive volatility. Evidence does not support the orthodox belief that, with free floating, international financial markets will perform that role by smoothly adjusting exchange rates to their "equilibrium" level. In reality, exchange rates under a floating regime have proved to be highly unstable, leading to long spells of misalignment. The experience with hard pegs has not been satisfactory either: the exchange rate could not be corrected in cases of external shocks or misalignment. Given this experience, "intermediate" regimes are preferable when there is instability in international financial markets.

Keywords: Exchange rate regime; external shocks; flexible exchange rates; financial markets; hard pegs.

JEL Classification: E4; F.

Global and regional imbalances in trade have been a major source of systemic risk to the market economy from the very outset. The reason for this is easy to

\footnotetext{
${ }^{1}$ This paper draws on Flassbeck/LaMarca (2009). Submitted: 27/June/2017; Approved: 26/July/2017.

${ }^{2}$ Division on Globalization and Development Strategies of the United Nations Conference on Trade and Development (UNCTAD), Geneve, Switzerland. E-mail: hflasssbeck@gmail.com.
} 
understand. The community of world economies has, except for the Gold Standard and a short time during the Bretton Woods era never been able to agree on a global monetary system that would have created favourable conditions to contain trade imbalances. Given that the adjustment under the Gold Standard has always been crisis prone and brutal, the period of a reasonable global system shrinks to some 20 or 30 years after the Second World War.

Indeed, global imbalances had adverse repercussions in the short and long term on both surplus and deficit economies due to the crises usually associated with them. External imbalances are undoubtedly affected by the determinants of international competitiveness such as wage and price inflation, productivity growth via real exchange rate changes as shaped by the institutions and regulation in the financial, labour and product markets. Nonetheless, it is widely acknowledged that speculative capital flows have a significant cumulative effect on exchange rates creating systemic risk on both the financial system and real economy.

The paper describes the paradox of the current pattern of world trade and financial imbalances where overvalued currencies may appreciate and undervalued currencies may depreciate. Indeed, the international adjustment mechanism can be undermined by many forms of speculative flows, which can be triggered by a combination of global conditions and domestic monetary policies and can lead to financial fragility and to real costs for the affected economies. The role of "carry trade" positions, broadly defined as highly-leveraged cross-country operations exploiting interest-differentials and low currency volatility, cannot be underestimated in the current diverging pattern of global imbalances and real exchange rates. The real costs of such form of speculation are enormous. Finally, it is pointed out how national and international policies need to address the major sources of imbalance by providing an institutional framework that would reduce the potential for speculative flows and promote coordinated efforts for exchange-rate adjustment and stable real exchange rates.

\section{WIDENING GLOBAL IMBALANCES}

The sources, sustainability and possible adjustment mechanisms of the widening external imbalances have been the object of one of the liveliest and most controversial economic policy debates of the past couple of decades. Trade flows correspond to real transfers of resources from surplus countries to deficit countries and are considered "imbalanced" when the inflows and outflows of a country vis-à-vis the rest of the world do not offset each other within a given period. On the basis of these accounting equivalences many observers have been claiming that imbalances are simply a natural and harmless consequence of an increasingly integrated global economy.

However, the actual pattern and level of the imbalances are a source of concern for those who believe that the size of any transfer of resources should remain within the expected long-run ability to pay interest and principal (UNCTAD, 2006; 
UN-DESA/UNCTAD, 2007). In fact, the size and the direction of net capital flows for many years following the shocks of the big financial crises in Asia, Latin America and some transition economies, tend to support the belief that something is wrong in the global imbalance adjustment mechanism.

Nonetheless, there is an almost universally shared belief that changes in the overall competitiveness of an economy can be a decisive factor in reversing the sign of its trade balance. Indeed, large corrections of deficits are usually observed to go hand in hand with huge devaluations of the nominal and real exchange rate, and empirical evidence has shown that changes in the real effective exchange rate (REER) - the most comprehensive measure of the overall competitiveness of nations (UNCTAD, 2004) - have the potential to reduce deficits or to induce swings in the trade and currentaccount from deficit to surplus (IMF, 2007 and Bundesbank, 2007). ${ }^{3}$

A depreciation of the real exchange rate, more than anything else, induces an "expenditure switch" from demand for foreign goods to demand for domestic goods, which is reflected in an improvement in the trade balance, and vice versa in the case of an appreciation. The swing from deficit to surplus in many crisis-stricken countries in Asia and Latin America was associated with huge devaluations of their currencies and large gains in competitiveness for their economies as a whole. This nexus between the exchange rate and trade flows is also acknowledged by those who believe that if the Chinese currency, the renminbi, were allowed to float freely, it would reduce the biggest surplus in the world and the biggest deficit at the same time.

Given this, few would question that a large or even rising current-account deficit, accompanied by a real appreciation and a loss in overall competitiveness, is a much stronger indicator of non-sustainability than a deficit and an overvalued currency alone. The currency of surplus countries is supposed to appreciate and not depreciate in real terms. If the most important price for exports and imports, the real exchange rate, consistently moves in the "wrong" direction, there is hardly an easy way out of a protracted imbalance. In other words, such "false" price movements should be avoided at all costs in order to allow the world economy to smoothly correct its global imbalances. But this "false pricing" is exactly what happens in many financial markets of the world.

\section{False Pricing is widespread in financial markets}

The best way to show the difficulty of the financial markets in general to estimate risk correctly and to find the right price is revealed by the comparison of markets for totally different "products" or "assets". In a number of papers at UNCTAD I have shown with a number of colleagues

that the daily movements of the CDS spread for Italy, a currency (the Brazilian

\footnotetext{
${ }^{3}$ REER is a comprehensive measure of competitiveness of an economy with respect to its trading partners. It is calculated as the average of bilateral real exchange rates weighted with annual values of trade.
} 
Real against the Yen) a commodity price (Brent crude) are highly correlated (Flassbeck and Boffa, 2010). This work was substantiated by work of my former colleagues David Bicchetti and Nicolas Maystre (see for example Flassbeck, 2013).

Over 24 months the currency, the price of oil and the spread go exactly in the same direction and the daily movements are extremely highly correlated. This parallel movement of CDS spreads and currencies demonstrate that the supposedly perfect information generation and processing on financial markets is flawed, and in particular the increasingly fanciful idea that markets are able to correctly understand the complex situation of a country in a crisis. Additionally, it is absolutely impossible that the movements of supply and demand for oil exactly mirror the movement of the risk of default of Italy. The only explanation of the homogeneity, for example since Spring 2009, is the homogenous expectation on all financial markets that a recovery has set in and that the train to the casino is leaving the station.

Here is the important distinction between financial markets and normal markets for goods and services. Atomistic markets for goods and services are able to generate and process a colossal quantity of independent information and data. Each market participant enters the daily bidding process with his or her specific plans to sell or to buy a certain product, which are based on his or her individual needs and preferences. The final price that is fixed by the market maker or auctioneer reflects all the different and independent bits of information and forms it into a fair price. The auctioneer, who is fixing the price every day or in even shorter periods guides the future plans of the individual actors and helps to overcome bottlenecks and gluts in the supply of certain goods.

Financial markets are totally different. Financial markets are characterized by oligopolistic information sharing. Most of the information that determines the behaviour and the expectations of speculators and hedgers are publicly accessible. Additionally and even more importantly, the interpretation of these data, which means their implications for expectations of the market participants, is rather homogenous. Many market participants do no longer have their own analysts on which they base their opinion but they rely on common software that determines or recommends selling or buying decisions based on a given number of indicators. That is why a certain event like bad news from the US labor market triggers selling of all risky assets at the same time and explains the strong correlation of the daily movements across all these markets.

There has long been a debate in economics concerning the "equilibrium price" in markets and the incompetence of governments in guiding the market to reach it. But that argument misses the point as far as financial markets are concerned: Even if well-informed governments and central banks do not exactly know the equilibrium price they usually do know when prices are in disequilibrium. The movement of prices on many seemingly "independent" markets in the same direction with extremely high correlation of the daily movements places the biggest question mark over the efficient market hypothesis. And in the realm of real-life 
economic policy, it moreover raises the political risk of a meltdown on all the markets at the same time.

The market determination of exchange rates through currency carry trade is the best example of herding and its dangers: exchange rates moving in the opposite of fundamentals, i.e., in the opposite direction of what is needed to restore the international competitiveness of the overall economy. After the biggest financial crisis since a century such phenomena should make all alarm bells ring and raise the pressure for government action to stop this kind of speculation.

Interventions in financial markets that are part of the global economy call for cooperation and coordination of national institutions and for specialized institutions with a multilateral mandate to oversee national action. In the aftermath of the biggest crisis in modern history this is even more important than in normal times. The tendency of many governments to entrust to financial markets again the role of judge or jury over the coming process of reform and indeed over the fate of whole nations would seem inappropriate. For example, it is indispensable to stabilize exchange rates by direct and coordinated government intervention. This should take the place of the usual government stance of allowing the market to find the bottom line while trying to "convince" financial markets of the credibility of the government of the depreciating currency through pro-cyclical policies like public expenditure cuts or interest rate hikes.

The overall lesson is a simple one: when it comes to finance, at least markets and rating agencies are not able to understand what is really going on in the complex interaction of markets, governments and citizens. They are not able to evaluate the future of societies and to find a reasonable price for the risk of default or any other severe shock. What makes us believe that anonymous participants on the financial markets should be able to generate knowledge that even the best and brightest brains are not able to produce?

\section{Persistent Global Imbalances}

Chart 1 shows the paradox of false pricing for a number of surplus economies with officially floating exchange rates: Switzerland, Norway and Korea are countries with officially floating exchange rates but have always intervened in the currency markets. Switzerland meanwhile struggles with a significant real appreciation, while Germany and the euro area as a whole have current account surpluses. Germany is clearly undervalued but hides behind the weakness of other euro area members. China, the country that had been most under political pressure to float its currency during the first years of the century, has reduced its surplus due to rigorous wage increases triggered by the government but small changes in the nominal exchange rates.

Under fixed exchange rates as well as under a floating regime, the real exchange rates can move in the wrong direction from a balance-of-payments point of view, thereby hindering the adjustment process and making the constellation of deficits and surpluses unsustainable. 


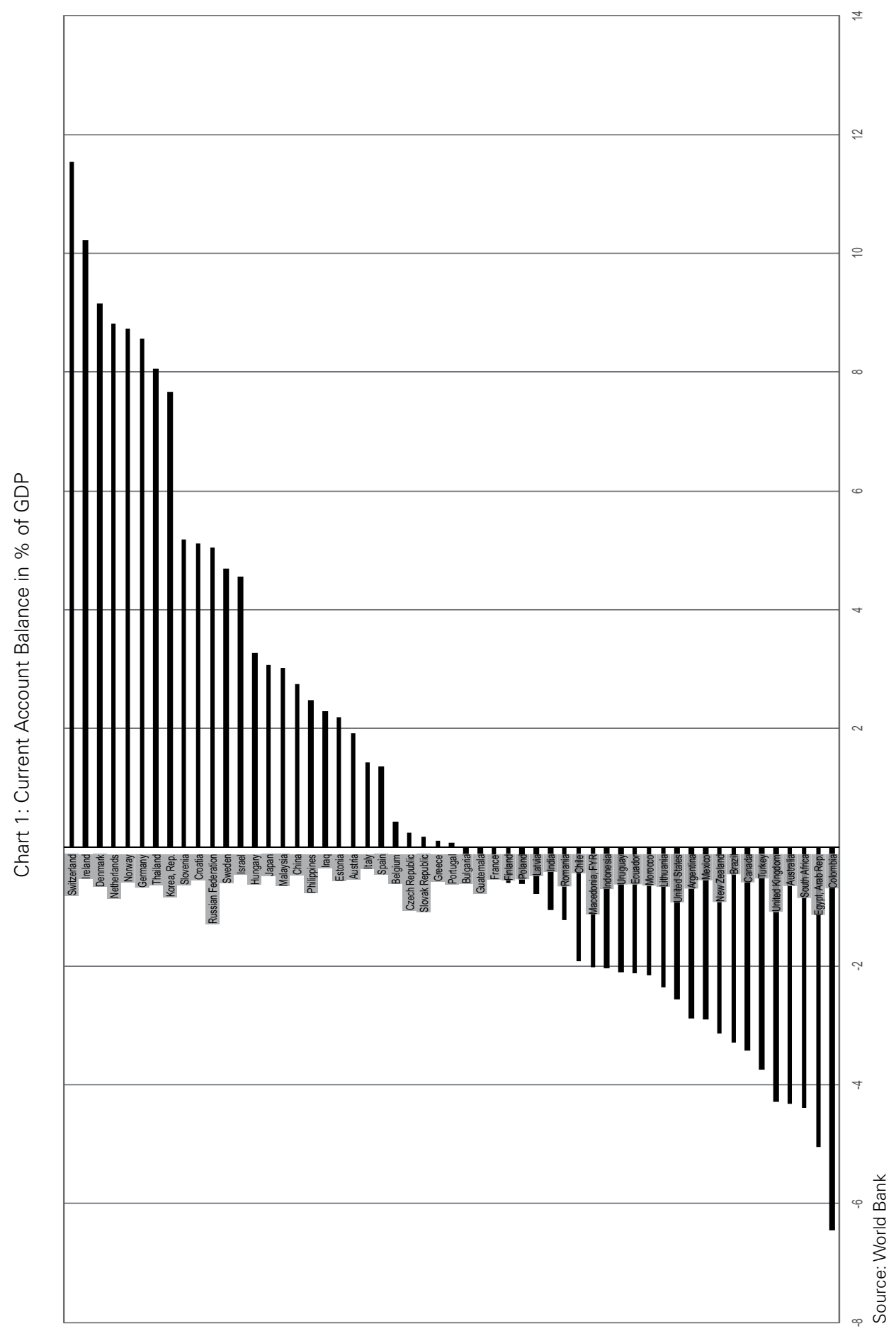


This suggests that the shift to floating and capital openness that was advocated by the Washington Consensus does not provide a solution to the global imbalances, and, more generally, raises questions about the role of the financial system in the determination of capital flows, nominal and real exchange rates and real imbalances. Indeed, various forms of domestic and international financial speculation have been associated with episodes of consumption booms, current-account deficits and overvalued currencies. If speculation is an important source of real exchange rate misalignments and of persistent diverging patterns of global real balances, domestic and international regulations and policies have to provide the conditions for generating converging patterns of trade balances and a coherent adjustment of the imbalances.

The following section describes how speculative capital flows, concomitant false pricing and the resulting misalignments are induced by short-term interest rate differentials and floating currencies in perfectly open markets. In light of the evidence, both policy targets for exchange rates and a new assignment of monetary and non-monetary instruments at the national level need to be reconsidered.

\section{Speculative flows induced by "carry trade"}

In the past couple of years, a widespread and persistent speculative phenomenon involving currencies of developed and developing countries with large shortterm interest rate differentials has drawn considerable attention from the media and financial analysts as well as concerns by central bankers. "Carry trade" has become a catchphrase to define the specific financial operation of borrowing and selling a low-yielding currency to buy and lend in a high-yielding currency.

For example, an established speculator such as a hedge fund might borrow 12,000 yen in Japan, buy 200 reals in Brazil, invest this amount in United States bonds and obtain an interest revenue equal to the difference between the borrowing rate in Japan, say 0.25 per cent, and the higher lending rate in the United States, say 5 per cent. Exchange rate changes between the time of borrowing and paying back the funding currency can add to the gains, or induce smaller gains or even losses. But with stable exchange rates, the interest rate gain amounts to 4.75 per cent. However, both gains and losses are largely magnified by high leverage ratios, since traders typically use huge amounts of borrowed funds and very little equity. For instance, owning a capital of $\$ 10$ and borrowing 10 times the equivalent of that value in yen, the leverage factor of 10 leads to a net interest return on equity of 47.5 per cent.

This simple and hardly new form of speculation may appear too straightforward to be possible in highly developed and integrated capital markets, yet it has represented a substantial source of profits, inducing huge amounts of capital flows and pressure on exchange rates since the collapse of the Bretton Woods system in the beginning 1970s. It has gained a new quantitative dimension, since more or less unregulated funds have nearly unlimited access to massive pools of capital from pension funds or wealthy citizens. 
Carry trade is fundamentally based on the expectation that, given a sufficiently large interest rate differential between the borrowing and the lending currency - which is quasi fixed by monetary policies in both countries - the exchange rate will either remain stable or move in a favourable direction, or allow a major withdrawal from the currency before profits are fully eroded. On the other hand, in today's markets, the volume of speculative flows stemming from these funds is so large that they have a direct effect on the exchange rate, thereby creating a selffulfilling expectation of profit in excess of the interest rate differential. In the example cited above, a devaluation of the yen and a revaluation of the dollar induced by carry trade would increase the net return on equity well beyond 47.5 per cent.

This implies that national policies aimed at fighting domestic inflation by rising interest rates may end up providing strong incentives to this kind of speculation. The ensuing over- or undervaluation may offset or magnify the effects of the desired monetary policies, generating financial fragility and huge real adjustment costs to the national economy and the global economic system. The fundamental mechanism of real-exchange-rate adjustment that, according to widespread political expectations, would allow a smooth correction of imbalances would be undermined. Flows moving from low-yielding, low-inflation countries to high-yielding, highinflation countries would cause the currencies of the latter to appreciate, and provoke the paradoxical and dangerous combination of surplus economies experiencing pressures to depreciate, and deficit countries facing a correspondent pressure to appreciate.

Carry trade in the past has involved mostly high- to medium-income economies such as Australia, Iceland, Japan, New Zealand, Switzerland and the United States, and a few emerging market economies such as Brazil, Turkey, South Africa, Republic of Korea, as well as some transition economies such as Hungary, Romania, Bulgaria and the Baltic states. Yen- and Swiss franc-funded carry trade operations appeared to be responsible for the large volatility and gyrations of some of the high-yielding currencies, such as the New Zealand and Australian dollars, the Hungarian forint, Brazilian real, Korean won and the Icelandic krona. The latter for instance experienced typical crisis symptoms: prolonged periods of steady appreciation and capital inflows, disrupted by shorter periods of sharp devaluations as carry traders unwound their positions.

Indeed, the dollar itself has been the target of "yen carry traders" and, to a lesser extent, of traders borrowing in Swiss francs, at least since the rise of the fed funds rate between 2004 and 2006. But the yen carry trade return potentials on the dollar have been low compared to uncovered returns plus real appreciation of a number of developing and transition economies against the dollar itself.

Other countries, such as Brazil and Turkey, have experienced a steady appreciation of their currencies despite fairly high inflation rates during the first decade of the century. The Brazilian and Turkish real appreciation and large interest rate differentials vis a vis the other major currencies and particular the yen have allowed for large gains in carry trade which persist despite the mid-2006 turbulence.

According to studies at the Bank for International Settlements (McGuire and 
Upper, 2007 and Galati et al.., 2007), hedge funds have been the main players and the main beneficiaries of trades using the yen and Swiss franc as funding currencies for buying assets in some of the countries mentioned above. A comparison of carry-to-risk ratios (the three-month interest rate differential divided by the implied volatility of the currency option) provides further evidence that there is a clear tendency for the currencies of some developing countries like the Brazilian real and the Turkish lira to become increasingly more attractive than traditional carry trade targets such as the Australian and New Zealand dollars and the pound sterling. However, speculative flows are difficult to identify and monitor. As noted in the BIS study, measuring the volume of carry trade is problematic because of lack of data and the variety of forms that these flows can take.

The specific episodes of carry trade deserve attention as warning signals that even financially developed medium- to high-income countries are not immune to destabilizing capital flows. Besides that, the phenomenon may be regarded as a "species" of the broader "genus" of potentially destabilizing speculative capitalaccount operations; it displays numerous similarities with the mechanisms that caused financial fragility in many emerging markets, leading thereafter to currency and financial crises in the mid-1990s. The more general mechanisms of destabilizing speculation, on the other hand, may easily involve emerging markets and small, open developing economies that have access to capital markets and adopt different monetary policies due to differing inflation histories. This has been shown during the global financial crisis of 2008 and 2009.

While such speculative operations naturally involve a currency risk for speculators, that can be attenuated by diversifying the portfolio of high-yielding currencies, the risk for both the funding and lending currencies cannot be diversified, and can therefore become a source of "systemic risk", spilling over from the financial system to the real economy. The web of different funding and lending currencies of otherwise unrelated economies causes the countries involved to become interdependent and subject to reversals of perceptions and to contagion.

Contagion spreads due to speculators' profit maximization motives: unwinding of positions in one country affects all the web-related economies. Such unwinding may be triggered by "conventional focal points" such as the external balance or growth, or the inflation prospects of the funding currency causing fear of an interest correction and an exchange-rate jump. For instance, it has been debated as to whether the speculative run on the Icelandic krona was triggered by the perceived non-sustainability of the huge current-account deficit, by a downgrade from some rating agency, or even by a piece of "good news" related to the funding currency, such as an improvement in the Japanese economy which had the potential of an interest rate increase and an appreciation of the yen. Undoubtedly, the carry trade unwinding from the krona in 2007 had a significant impact not only on the Icelandic financial and credit system, but also on some third parties involved, namely some emerging markets such as Brazil and Turkey, as traders needed to cash in some of their earnings from well-performing currencies to cover some of their losses from the krona trade. 
While uncovered gains and losses can be significant, their volatility depends entirely on fluctuations in the nominal exchange rate. Periods of relative stability and large interest rate differentials provide strong incentive to traders, as in 2005 and late-2006. During that period the dollar appreciated vis-à-vis the two funding currencies, despite high and rising current- account deficits and higher inflation rates in the United States than in Japan or Switzerland. On the other hand, the carry trade is such a psychological game that does not require big changes in the interest differentials to be reversed. The yen and dollar movements are under scrutiny and has become focal points that can trigger wider reversal. A sudden pick up of expected volatility, as in the mid-2006 and in the summer 2007, can trigger a large unwinding of investments and spill over to emerging market economies. Currency volatility discourages carry trade operation by raising the risk that gains from interest differentials between the funding and the target currency may be eroded by adverse exchange rate movement. On the other hand, the reversal of the positions generates the volatility and the adverse exchange rate changes that lead to further reversal of the flows.

\section{Domestic policies and speculation opportunities}

The experience of Mexico and Brazil (and to a lesser extent in Argentina) regarding the evolution of inflation and interest rates, as well as of nominal and real exchange rates, has dominated the picture of Latin America.

Prior to the 1999-crisis, the situation in Brazil was characterized by an overvalued real exchange rate and a large differential between domestic and international interest rates aimed at maintaining capital inflows. During the same period, Mexico also had high domestic interest rates, while relatively high inflation rates were appreciating the real exchange rate. Brazil's 1999-crisis forced a large nominal depreciation of the real and led to an interest rate hike that also affected interest rates in Mexico and Argentina. After the 1999-crisis, Brazil adopted a floating exchange rate regime and implemented an inflation-targeting monetary policy (Barbosa, 2006). The 2001-crisis in Argentina and the 2002-depreciation of the Brazilian real triggered a surge in inflation rates following by a rise in interest rates. While interest rate differentials aimed at curbing inflation have been significantly reduced, Brazil still offered considerable potential gains for short-term speculation after 2001 . Argentina, on the other hand, was able to contain real appreciation and succeeded in moderating inflation although preserving low interest rates for a time.

The empirical picture for the group of African developing countries is dominated by South Africa. Following the adoption of inflation targeting, South Africa has experienced large nominal and real appreciation that have undermined its competitive position and led to a large current account deficit time and again. Turkey provides an example of frequent changes in the monetary regime, resulting in large and volatile nominal exchange-rate changes and frequent real appreciation (mostly induced by large inflation rate differentials), and constantly associated with 
large uncovered returns on short-term capital (generated by the large interest rate differentials).

Asian countries have mixed experiences. China has adopted a pegged exchange rate and other economies have managed or independent floating. Experience of the group as a whole has been characterized by very moderate inflation and low interest rates, which has stabilized expectations of investors in fixed capital and limited short-term speculative capital inflows.

Regarding China, its exchange rate, capital market and monetary regimes have been very stable over a long period of time. A pegged exchange rate, limited convertibility, low inflation and low interest rates have led to expectations of stability by investors in fixed capital, and have not attracted large amounts short-term carry-trade speculators. Low nominal and real interest rates have caused short-term speculative profit returns to be nil or even negative, thereby discouraging speculative capital inflows of the carry trade type. The other economies of the region have recently experienced exchange rate volatility and real appreciation.

In the past, in many cases managed depreciation or pegging of exchange rates, associated with large interest rate and inflation rate differentials, have led to real appreciation and the loss of competitiveness, and have offered opportunities for speculation. This occurred to a large extent in pre-crisis Brazil, Thailand, the Republic of Korea and the Russian Federation in the 1990s. Unfortunately, the regime switch to floating and inflation targeting improved the situation only in those countries that were able to consistently reduce their interest rate differential against the United States. In many other cases, despite slightly lower inflation and interest rate differentials, the tendency towards real appreciation continued unabated.

Moreover, the opportunities for international speculation, though subject to larger exchange-rate risk, have not faded; instead, they remain a major source of instability and risk. Short-term interest rates, as the main instrument to combat inflation, have generated new opportunities for large-scale speculation on the currency market. The real costs for the economies will be very high if the restrictive effects of chronic real appreciation add to high real interest rates and penalize non-subsidized domestic capital formation.

\section{Changing speculation opportunities in emerging market economies}

Carry trade, as any other form of speculation on international interest rate differentials that is not covered in the forward currency market, involves a currency risk. Speculative capital flows typically respond to short-term current and expected monetary variables, such as the interest rate, the exchange rate, liquidity and risk. A floating exchange regime supposedly increases the risk and discourages such operations, while a fixed exchange regime provides a (partial) guarantee of exchange stability, and therefore encourages speculation. However, specific experience of carry trade in officially floating currencies does not confirm this hypothesis. Indeed, floating currencies under various monetary policy regimes, rather than 
being immune to speculative operations actually stimulate them if the amounts available to investors are big enough to drive the market in a certain direction.

Integrating risk into the analysis implies fundamental difficulties in assessing attraction for speculative capital flows and their effect on the real exchange rate. One difficulty is related to the definition and measurement of expectations and of perceived risk, because they are very sensitive to arbitrary behavioural assumptions. For the sake of simplicity, we look again at the ex-post uncovered interest rate returns, and take the associated currency volatility as a measure of risk, to figure out what, on average, could be the gains from speculation, bearing in mind that expectations can be strongly adaptive under rather predictable environments. This implies that even a floating exchange-rate regime can provide a stable and comfortable environment for speculators as long as exchange rates do not systematically offset interest rate margins and the exchange rate movements can be influenced by the herd behaviour of speculators.

This raises the question of how to come to grips with a central tenet of macroeconomic analysis, the assertion that there are always strong stabilizing forces on the capital market which will tend to quickly remove any arbitrage gain and lead to the uncovered interest parity (UIP). The UIP states that capital flows find equilibrium when the expected devaluation of a currency compensates for the interest rate differential obtained by investing in that currency and represents a fundamental tenet of our theoretical conventional wisdom and a building block of standard macroeconomic models. Capital inflows and outflows would find equilibrium if the incentive to buy a currency and invest abroad, driven by an interest rate spread, is completely offset by the potential loss of the currency value, that is, if the positive interest rate spread is compensated by an expected devaluation of the exchanged currency.

This implies that assets denominated in a different currency should have the same return so that no extra profit can be made by exchanging them. On the other hand, it also implies that it should not be profitable to short- sell or borrow in a currency and lend uncovered in another. The uncovered interest parity condition is therefore an equilibrium condition that rules out excess demand in the international market. Coupled with the assumption that expectations are formed in a fully rational way (market participants use efficiently all the information available), it becomes a manifestation of the market efficiency hypothesis that states that any security prices (exchange rate included) reflect all available information, and that no unexploited extra profit is possible.

The literature on the validity of parity has been extensive and has strongly rejected the joint assumptions of UIP and of exchange rate expectations on the basis of "perfect rationality". Attempts to solve the rational-expectation UIP puzzle either by adding a time varying risk premium, or by assuming a transitional learning period, or by adding "noisy traders", have delivered theoretically and empirically controversial results.

The carry trade phenomenon, as well as many other profitable speculative activities, not only clearly violate the parity condition, but also give additional sup- 
port to its related "forward-premium puzzle" (Burnside et al.., 2007). The evidence that currencies at a forward premium tend to depreciate while currencies at a forward discount tend to appreciate implies that positive interest rate differentials are systematically associated with appreciation. The parity can preserve its theoretical relevance for analysing the possible market equilibrium configurations by avoiding any strict assumptions on expectation formation and determination of perceived risk.

Traditional macroeconomic analysis would assume that currency volatility tends to reduce any form of speculation. However, even allowing for a certain degree of risk aversion on the part of speculators (meaning that for identical expected returns they will choose the assets with a smaller risk), exchange-rate flexibility does not discourage portfolio and currency speculation unless interest rate differentials could be offset by the risk of depreciation, in periods of extreme volatility. In particular, if the herd behaviour of speculators is sufficient to influence appreciate the target currency, the appeal of large returns is sufficient to generate them.

\section{National policies to prevent speculation}

For small open economies, and developing countries in particular, a stable and prospering external sector is crucial. That is why the exchange rate is the most important single price in these economies, as it dominates overall competitiveness and has a strong impact on the national price level. Recent studies have found that a "competitive and stable" real exchange rate is a key economic policy tool for developing countries because it enables a persistent pattern of export expansion and investment growth based on a profit-investment nexus (UNCTAD 2004 and 2006; Rodrik, 1995) allowing to take advantage of favourable fundamentals, externalities and proper institutions (Eichengreen, 2007). The challenge for national policies is to combine the control of inflation rates, which has taken centre stage in many developing countries, with international competitiveness and low exchange-rate variability and in a world of free and volatile short-term capital flows.

As emphasized in UNCTAD (2004, chap. IV), large inflation differentials lead to large interest rate spreads, because central banks use the interest rate as the principal instrument to curb inflation via a contraction in credit and demand. But nominal returns are the focus of carry trade by financial investors. These investors are not concerned with inflation differentials and other fundamentals per se, as long as they do not constitute a threat to the stability of the currency and therefore to their expected profits. The capital inflows induced by nominal interest rate spreads, coupled with an exchange rate that is perceived as either stable or appreciating, on average, or even depreciating but still allowing for sufficient returns, have huge repercussions for the real economy and for current-account imbalances worldwide.

The financial and real systemic effects of portfolio capital inflows vary according to the specific institutional, structural and even cyclical situation of the recipi- 
ent economy. Financial development and intermediation, the size of the inherited internal and external debt, the composition of production and of the trade balance affect the capacity to absorb the flows and their impact on relative prices and on growth. Nevertheless, the scenarios that characterize emerging market financial fragility and volatility share common features.

Under a fixed exchange rate or crawling peg regime, capital inflows boost reserves, money creation and credit expansion, which may induce consumption growth and inflation and an import surge. Under an officially floating exchange regime, they can induce nominal and real appreciation and increase reserves to the extent that the central bank, openly or implicitly, is willing to contain exchange-rate changes. There may be a time lag in their effects on the real side of the economy but it may be critical. An overvalued exchange rate penalizes exports and reduces competitiveness, and therefore the growth of firms in the traded-goods sector. This in turn adversely affects income and growth in general. Finally, deteriorating economic conditions may make the country the object of a renewed focus on "bad fundamentals"; the exchange rate may sharply devalue and the central bank's ability to contain inflation may be called into question.

If targeting inflation via interest rates involves serious additional costs by inducing capital inflows, such anti-inflationary strategies have to be weighed against alternatives that might be less tried and tested but may yield significant longer run real benefits. These alternatives may be found in the new and heterodox national macroeconomic policies applied with outstanding success in most of Asia (UNCTAD 2006 , chap. IV, D.). In this approach, monetary policy focuses mainly on the external sector, including the exchange rate. Inflation is controlled by other factors and policies than those controlled by the central bank: typically, well-designed income policies taking into account the existing labour market institutions have played a leading role.

Avoiding large gains for foreign investors from short-term arbitrage operations keeps the actual rate of appreciation in check and cuts the link between these capital flows and the real exchange rate, thus maintaining a country's competitiveness. Successful countries were consistently able to prevent persistent real appreciation. This may require policies to restrain short-term capital inflows and outflows through regulation as long as the expected profitability from speculation cannot be reduced by a traditional set of policies like an interest rate reduction. Internal and external debt restructuring may help limit the effect of international speculation by reducing nominal interest rates.

\section{Globally coordinated policies to reduce global imbalances}

The on-going carry trade from the yen or Swiss franc, from countries with very low inflation and very low nominal interest rates to countries with higher inflation and higher interest rates, such as Brazil, Hungary or New Zealand, breaks the vital link between interest rate differentials and the risk of currency depreciation. If floating exchange rates do not follow the purchasing power rule in the short term 
and destabilize the external accounts, then international policy should aim at preserving this rule as a policy target. Unhedged borrowing by hedge funds and other speculators more than anything else raises questions about the wisdom of widespread acceptance of floating as the only feasible solution to the problem of the external balance.

That is why the political pressure on China to float its currency may end up producing exactly the opposite of the result expected. As China's interest rates are still rather low, it is by no means clear that the renminbi will appreciate if China were to give in to the pressure from the United States and float its exchange rate. The renminbi might risk following the examples of the yen and the Swiss franc and be carried to high interest rate locations. If that were to happen, it would depreciate and cause a further increase in China's competitiveness instead of reducing it. Such an outcome would clearly worsen the global imbalances.

Developing countries in general need flexibility and a sufficient number of instruments to prevent excessive volatility of the whole external sector which threatens long-term investment and successful catching up. Evidence does not support the orthodox belief that, with free floating, international financial markets will perform that role by smoothly adjusting exchange rates to their "equilibrium" level, while with fixed exchange rates, product, financial and labour markets will always be flexible enough to smoothly and rapidly adjust to a new equilibrium. In reality, exchange rates under a floating regime have proved to be highly unstable, leading to long spells of misalignment, with grave consequences for the real economic activity of the countries concerned. The experience with hard pegs has not been satisfactory either: the exchange rate could not be corrected in cases of external shocks or misalignment, adjustments were costly in terms of lost output, and the real sectors of the domestic economy bore the brunt.

Given this experience with rigidly fixed and freely floating exchange rates, "intermediate" regimes have become the preferred option in most developing countries with open capital markets; they provide more room for manoeuvre when there is instability in international financial markets and enable adjustment of the real exchange rate to a level more in line with a country's development strategy. None of the "corner solutions" offer these possibilities. Developing countries that are not members of a regional monetary arrangement that could deal with the vagaries of the global financial markets thus have to resort to controls of short-term capital flows or adopt a strategy of undervaluation and unilateral fixing (UNCTAD, 2004).

To prevent manipulation of the exchange rate, wage rates, taxes or subsidies in the bid for global market shares, and to deter the financial markets from driving the competitive positions of nations in the wrong direction, a new code of conduct is needed that would regulate the overall competitiveness of nations. Such a code of conduct, as part of the global governance system, would have to balance the advantages of one country against the disadvantages of other, directly or indirectly, affected countries. For example, changes in the nominal exchange rate that deviate from the fundamentals (inflation differentials) affect international trade in exactly the same way as do changes in tariffs and export subsidies. Consequently, such real 
exchange-rate changes have to be subject to multilateral oversight and negotiations. Reasons for the deviation from the fundamentals and the necessary size of the deviation have to be identified by an international institution and enforced by a multilateral body. Such rules could help protect all trading parties against unjustified overall losses or gains from competitiveness, and developing countries could systematically avoid the trap of overvaluation that has been one of the major impediments to prosperity.

A long-term solution for the international financial system has to start with the recognition that the idea of a cooperative global monetary system is as compelling as the idea of a multilateral trading system. As with multilateral trade rules, a well-designed global financial system has to create equal conditions for all parties involved and help prevent unfair competition. Indeed, reasons for which the International Monetary Fund (IMF) was founded more than 60 years ago are still largely valid. Avoiding competitive depreciations and other monetary distortions that have negative effects on the functioning of the international trading system is more important in today's highly interdependent world than at any other time in history.

\section{REFERENCES}

BARBOSA, N. H. (2006). "Inflation targeting in Brazil: Is there an alternative?" Political Economy Research Institute, Amherst, MA.

BUNDESBANK (2007). Bundesbank monthly report. June 2007: 35-56. Frankfurt am Main, Germany. BURNSIDE, C., M. EICHENBAUM and S. REBELO (2007). "The returns to currency speculation in emerging markets”, NBER Working Paper No. 12916, February 2007.

EICHENGREEN, B. (2007). "The real exchange rate and economic growth". Unpublished paper presented at the Conference "Macro economics and financial policies for sustained rapid growth" of the World Bank's Commission on Growth and Development, New York, NY, 09 April 2007.

FLASSBECK, H. and M. La MARCA (2009): "Global imbalances and destabilizing speculation", in: http://www.ccmf-uwi.org/files/publications/journal/2009_1_4/149_196.pdf

FLASSBECK, H. (2013). "When commodities are "just" another asset by David Bicchetti and Nicolas Maystre”, https://makroskop.eu/2013/02/when-commodities-are-just-another-asset-by-david-bicchetti-and-nicolas-maystre/

FLASSBECK, H. and S. BOFFA (2010). "The wisdom of the herd- What the financial markets can tell about sovereign risk". Swiss Derivative Magazine, January 2010.

GALATI, G., A.HEATH and P. McGUIRE (2007). "Evidence of carry trade activity". BIS Quarterly Review, September 2007.

IMF (2007) "Exchange rates and the adjustment of external imbalances". World Economic Outlook. Washington, DC, International Monetary Fund.

McGUIRE, P. and C. UPPER (2007). “Detecting FX carry trades”. BIS Quarterly Review, March 2007: 8-9.

RODRIK, D. (1995) “Getting interventions right: how South Korea and Taiwan grew rich”, Economic Policy 20: 53-107.

TELLI, C, E. VOYVODA and E. YELDAN (2007). "Macroeconomics of twin-targeting in Turkey: Analytics of a financial CGE model”. Political Economy Research Institute, Amherst, MA.

UN-DESA/UNCTAD (2007). World Economic Situation and Prospects. New York, United Nations.

UNCTAD (various issues). Trade and Development Report. 